\title{
DUAS TESES RECENTES DE DIREITO CIVIL
}

\author{
Alexandre Augusto de Castro Corrêa \\ Professor Catedrático da Faculdade de Direito da \\ Universidade de São Paulo
}

A primeira é a do professor Álvaro Villaça Azevedo, sobre Prisão Civil por Dívida. O autor, por considerá-la incompatível com os princípios do Direito Civil, condena a prisão decretada contra o depositário infiel e contra o devedor inadimplente da obrigação de prestar alimentos. Considera-a intromissão indevida do Direito Penal no âmbito do Direito Privado e contrária ao estado atual da ciência. $\mathrm{Na}$ introdução de seu trabalho escreve à p. 8: "Estudaremos aqui o resquício violento da execução pessoal do devedor de alimentos e do depositário infiel que tisnam o preceito constitucional de que ninguém pode ser preso por divida. Procuraremos, desse modo, extirpar do nosso texto magno essa reminiscência dum passado já condenado e inoperante".

Fazendo o histórico da questão na antigüidade, o autor apresenta longo e erudito apanhado sobre o Direito Romano, fonte principal, como se sabe, do moderno Direito Civil. E nas "Considerações Finais" continua: "A prisão civil por dívida pode intimidar mas não é solução, atualmente, em que as prisões são insuficientes até para conter, condignamente, elementos perigosos da sociedade. Muito menos têm capacidade física para conter, em seu recinto pernicioso, contratantes e membros de família". E alude ao dano moral por essa prisão causado ao devedor insolvente bem como à violação de seus direitos de personalidade, "nutrindo coerção sem pena, no patente ilogismo mostrado no decurso desta obra"

$\mathrm{O}$ autor preconiza medidas processuais substitutivas da prisão civil de modo a executar-se o patrimônio e não a pessoa do devedor; tais medidas consistiriam na oneração por multas e despesas de remoção de bens, e naturalmente na condenação ao pagamento das custas processuais, de modo a ficar o devedor desmotivado a praticar qualquer sonegação de bens ou de pagamento. O Direito Civil ver-se-ia assim expurgado de anacrônico e desumano modo de coagir o devedor, e a ciência atual do Direito Civil, por seu lado, veria atendida uma exigência de autonomia do Direito Privado. Tal em substância parece o pensamento do autor. 
Prisão civil. O autor reconhece, como não poderia deixar de fazer, que a prisão civil não é castigo imposto em consequiência de condenação penal, mas simples meio de coagir o devedor ao cumprimento da obrigação: essa prisão, decretada pelo magistrado, pode, a qualquer momento, ser por ele revogada caso ocorra o adimplemento; nem sua duração, segundo o art. 1.287 do Código Civil ultrapassará o prazo de um ano.

Não há, pois, confusão entre o emprego de meios coercitivos nos casos previstos em lei e a prisão por dívidas, hoje abolida e decorrente de condenação penal em razão de mera insolvência, como se, independentemente de sua boa ou máfé, o devedor inadimplente devesse considerar-se verdadeiro estelionatário. Resta, pois, a questão da conveniência ou inconveniência moral e prática do emprego da medida, bem como a de sua presença no âmbito do direito privado.

$\mathrm{O}$ autor não se impressiona com os argumentos favoráveis à prisão civil, rejeitando os in totum.

Às pp. 164-5 de sua tese aduz textos expressivos de juristas brasileiros partidários da prisão civil, tais como Arnaldo Marmitt, João Claudino de Oliveira e Cruz e Sérgio G. Pereira. Mas, conclui: "Todavia continuamos a entender que a prisão civil por dívida, como restará, afinal, demonstrado não é o meio civilizado e humano da realização da justiça do cumprimento obrigacional, na área do Direito Privado".

\section{Observações pessoais do autor desta resenha}

As razões favoráveis à manutenção da prisão civil parecem, data vênia, mais acertadas, pelo menos relativamente ao nosso ambiente social. Por outro lado, dentre os direitos de personalidade em confronto o "direito personalíssimo à própria vida" (p. 164), no caso de abandono de família é sem dúvida mais relevante. Quanto ao depositário infiel, sua prisão civil atende à necessidade lembrada por Troplong (p. 38 da tese) de se reprimir "uma espécie de violação da fé pública"

Aliás, se quisermos levar às últimas conseqüências a opinião contrária a qualquer resquício de presença do Direito Penal na esfera do Direito Privado talvez devêssemos também propor a revogação entre outros dos artigos de nosso Código Civil sobre suspensão e extinção do pátrio-poder, indignidade e deserdação, sonegação de bens hereditários, cobrança de dívida já paga, casamento de viúva sem fazer inventário e dar partilha aos herdeiros do casamento anterior, e que cominam verdadeiras "penas" civis. 
Estas ligeiras críticas, porém, em nada diminuem o brilho do trabalho do professor Villaça, unanimemente aprovado em memorável concurso de cuja banca examinadora tivemos a honra de participar.

A outra tese recente de Direito Civil é a do professor Carlos Alberto Bittar sobre Reparação civil dos danos morais. O tema é de grande atualidade no Brasil, se lembrarmos que só em 1970 o Supremo Tribunal Federal, por acórdão unânime do Tribunal Pleno, admitiu sem qualquer restrição a reparabilidade direta do dano moral num caso de menor, morto em acidente de trânsito: "Inclui-se na condenação a indenização dos lucros cessantes e do dano moral, além das despesas de funeral, luto e sepultura" E essa orientação foi seguida posteriormente nos casos de dor, mágoa ou tristeza inflingidas a outrem sem justa causa.

A exposição do autor aborda vários tópicos atinentes ao tema, dentre os quais realçamos os seguintes: Danos materiais e danos morais (pp. 32-40); reparabilidade plena dos danos morais (pp. 101-110); reparações cumulativas de ambos os danos (pp. 229-231). À p. 236 escreve judiciosamente o professor Bittar: "Fundada na noção de preservação da individualidade, essa teoria (da responsabilidade por dano moral) tem assento no princípio geral do neminem laedere, incluido entre os identificadores do denominado Direito Natural, ganhando vulto nos planos dos direitos autorais e de personalidade" Mostra, em seguida, como, na falta de textos expressos no Código Civil, a Constituição de 1988 nos incisos $\mathrm{X} \mathrm{e} \mathrm{V}$ assegura a reparação dos danos morais.

\section{Observações pessoais do autor desta resenha}

Distinguindo-se pela análise inteligente e erudita dos aspectos mais relevantes de seu tema, o trabalho do professor Bittar merece leitura atenta por parte de todos os interessados no assunto. Seria, talvez, recomendável historiar a evolução da jurisprudência brasileira desde 1950, que parte da inadmissibilidade da indenização por danos morais, quando deles não resulte dano patrimonial (como no caso de homicídio culposo de filho menor que não-trabalhava) até chegar à Súmula 491, declarando "indenizável a morte de filho menor, ainda que não exerça trabalho remunerado". Essa orientação é, aliás, consagrada pelo inciso $\mathrm{X}$ do art. $5^{\circ}$ da Constituição de 88 , lembrado pelo autor.

Outro aspecto, agora doutrinal, suscitado pelo professor Sílvio Rodrigues in Responsabilidade Civil (pp. 188 e ss. da edição Saraiva de 1995) é o representado pelas seguintes questões: a) falta de efeito durável do dano meramente 
moral; b) prova difícil da existência do dano; c) número indeterminado de pessoas lesadas; d) impossibilidade de rigorosa avaliação em dinheiro da extensão do dano moral; e) poder discricionário concedido ao juiz nesta matéria. Tais são, como se sabe, as mais importantes objeções opostas pelos adversários da indenização por dano puramente moral. A este propósito Weil e Terré em seu Droit Civil Les obligations ( $2^{\mathrm{a}}$ ed., Dalloz, 1975, §§ 614-615) observam: "Quando o prejuízo sofrido... reveste caráter extrapatrimonial, sua reparação pode suscitar objeções quando se tratar de dor moral, pois pode ser chocante ir mendigar em juízo as próprias lágrimas" E citam Le prix de la douleur, de Ripert e La commercialisation du dommage moral, de Esmein.

Os mesmos autores prosseguem comentando o "prejuízo de afeição": "Foi sobretudo a propósito da reparação da dor moral sentida em razão da morte de pessoa querida ou mesmo de seus sofrimentos físicos que se pôde perguntar se a jurisprudência não tinha ido longe demais na indenização dos prejuízos de afeição (prevista igualmente no art. 1.543 de nosso Código Civil). Essa crítica é difícil de arredar, quando se evocam os casos extremos de indenizações atribuídas em reparação do prejuízo de afeição sofrido pela morte de um animal"

E ponderando a respeito da imoralidade consistente em se procurar compensar com dinheiro a dor experimentada pela vítima, o professor Sílvio Rodrigues (ob. cit., p. 190, n. 178) recorda a pergunta de Demogue (in Les obligations, v. IV. n. 408): "Dever-se-á ir a ponto de conceder indenização ao marido traído por sua mulher?"

$\mathrm{O}$ exame detido destas questões que parecem relevantes enriqueceria a monografia do autor, a qual, nem por isso, deixa de ocupar posição de primeira grandeza na bibliografia nacional sobre assunto de permanente interesse.

São Paulo, fevereiro de 1996. 